2 Konotey-Ahulu, F I D, Lancet, 1965, 1, 1003.

3 Addae, S, Lancet, 1971, 2, 1256.

4 Isaacs-Sodeye, W A, personal communication, 1974.

${ }^{5}$ Diggs, L W, and Flowers, E, Clinical Paediatrics, 1971, 10, 697.

6 Seeler, R A, Lancet, 1973, $2,743$.

7 Amjad, H, Bannerman, R M, and Judisch, J M, British Medical fournal, $1974,2,54$

${ }^{8}$ Serjeant, G R, The Clinical Features of Sickle Cell Disease. Amsterdam, Elsevier, 1974

${ }^{9}$ Rubinstein, E, American fournal of Medicine, 1961, 30, 95.

10 Marsden, P D, and Shah, K K, Fournal of Tropical Medicine and Hygiene, $1964,67,31$.
11 McSweeney, J E, Mermann, A C, and Wagley, P F, American fournal of Medical Science, 1947, 214, 542.

12 Burchmore, J W, et al, Lancet, 1962, 2, 1008.

13 Charmot, G, Reynaud, R, and Bergot, J, Lancet, 1963, 2, 540.

${ }^{14}$ Robinson, M G, and Sathiapalan, R, Lancet, 1965, 2, 957.

15 Hammel, C F, et al, British fournal of Haematology, 1973, 25, 593.

${ }^{16}$ Alavi, A, et al, fournal of Nuclear Medicine, 1974, 15, 1003.

${ }_{17}$ Charache, S, and Page, D L, Annals of Internal Medicine, 1967, 67, 1195.

18 Ward, E E, in Proceedings of 20th Scientific Meeting of Commonwealth Caribbean Medical Research Council, St Lucia, April 23, 1975, p 15.

19 Manfredi, F, et al, Circulation, 1960, 22, 602.

\title{
Cervical diameter after suction termination of pregnancy
}

\author{
F D JOHNSTONE, R J BEARD, I E BOYD, T G MCCARTHY
}

British Medical fournal, 1976, 1, 68-69

\section{Summary}

The diameter of the internal cervical os was measured in several groups of patients in an attempt to assess any damage caused by suction termination of pregnancy. Pregnant women who had had a previous abortion by vacuum aspiration had significantly greater cervical diameters than those who had not, and there was a statistically significant correlation between dilatation of the cervix at operation and cervical diameter at six weeks' follow-up. Cervical dilatation to $10 \mathrm{~mm}$ or less was subsequently associated with a normal cervical diameter, but the diameter was often large when the extent of dilatation was greater than $12 \mathrm{~mm}$ or not known. Cervical dilatation at termination of pregnancy should, if possible, not exceed $10 \mathrm{~mm}$.

\section{Introduction}

Cervical damage has long been recognised as a hazard of dilatation of the cervix for induced abortion. Reports from several countries have suggested an association between induced abortion and subsequent second trimester abortion or premature delivery. In none of these studies, however, was there a carefully matched control group. Furthermore, techniques of first trimester abortion have changed, and these figures do not necessarily apply to current methods.

Patients with cervical incompetence may be identified by an abnormally wide internal os diameter. The introduction of a simple method of measuring this diameter led to an attempt to assess this after abortion.

Institute of Obstetrics and Gynaecology, Chelsea Hospital for Women, London SW3

F D JOHNSTONE, MB, MRCOG, resident surgical officer (now lecturer, University Department of Obstetrics and Gynaecology, Aberdeen AB9 2ZD)

R J BEARD, FRCs, MRCOG, senior registrar (now consultant gynaecologist, Brighton General Hospital, Brighton 7)

I E BOYD, FRCS, MRCOG, senior registrar (now consultant gynaecologist, Southampton General Hospital, Southampton SO9 4XY)

T G MCCARTHY, FRCS, MRCOG, resident surgical officer (now senior registrar, St Thomas's Hospital, London SE 1)

\section{Patients and methods}

There were four groups of patients. Group 1 consisted of eight non-pregnant women with a history of at least two spontaneous midtrimester abortions and a presumptive diagnosis of cervical incompetence. Group 2 consisted of 16 pregnant women whose cervix was measured at repeat suction termination of pregnancy. Group 3 consisted of 51 women who had their cervix measured six weeks after their only suction termination of pregnancy. Group 4 consisted of 17 non-pregnant women who had had a previous suction termination of pregnancy but who had not been pregnant in the past year.

The measurements were carried out as described. ${ }^{1}$ The French catheter gauge system was used ( 1 gauge French $=0.33 \mathrm{~mm}$ ). The results were compared with published normal values obtained from 99 pregnant and 41 non-pregnant women. ${ }^{1}$ This study gave the following standard (mean SD) values: (a) a non-pregnant mean cervical diameter of $24 \cdot 3 \pm 3 \cdot 1$ French, $(b)$ a nulliparous pregnant mean cervical diameter of $25 \cdot 8-3 \cdot 1$ French, and $(c)$ a parous pregnant mean cervical diameter of $27 \cdot 3 \cdot 3 \cdot 3$ French.

TABLE I-Cervical measurements in patients who had had previous midtrimester abortions (group 1)

\begin{tabular}{|c|c|c|c|c|c|}
\hline $\begin{array}{l}\text { Case } \\
\text { No }\end{array}$ & Gravidity & Parity & History & $\begin{array}{l}\text { Day of } \\
\text { cycle }\end{array}$ & $\begin{array}{l}\text { Cervical } \\
\text { diameter } \\
\text { (French } \\
\text { gauge) }\end{array}$ \\
\hline 1 & 3 & 0 & $\begin{array}{l}\mathrm{D} \text { and } \mathrm{C} \text { for dysmenorrhoea } \\
\text { (twice), } 3 \text { painless second } \\
\text { trimester abortions }\end{array}$ & 6 & 37 \\
\hline 2 & 5 & 0 & $\begin{array}{l}\text { Suction termination of } \\
\text { pregnancy (twice), } 3 \\
\text { painless second trimester } \\
\text { abortions (16, 19, and } 22 \\
\text { weeks), cervical } \\
\text { incompetence diagnosed on } \\
\text { hysterogram }\end{array}$ & 26 & 40 \\
\hline 3 & 4 & 0 & $\begin{array}{l}\text { Sunction termination of } \\
\text { pregnancy, } 1 \text { 1st trimester } \\
\text { abortion, } 2 \text { 2nd trimester } \\
\text { abortions, no details }\end{array}$ & 9 & 30 \\
\hline 4 & 3 & 0 & $\begin{array}{l}16 \text { Weeks abortion (pain and } \\
\text { bleeding), } 16 \text { weeks } \\
\text { abortion (spontaneous } \\
\text { rupture of membranes, } \\
\text { fairly painless labour), } \\
13 \text { weeks abortion }\end{array}$ & 12 & 31 \\
\hline 5 & 8 & 0 & $\begin{array}{l}4 \text { 1st trimester, } 4 \text { 2nd } \\
\text { trimester miscarriages, } \\
\text { several Shirodker sutures }\end{array}$ & & 24 \\
\hline 6 & 5 & 3 & $\begin{array}{l}\mathrm{D} \text { and } \mathrm{C} \text { for dysmenorrhoea, } \\
3 \text { full-term pregnancies } \\
\text { uneventfully, } 16 \text { weeks } \\
\text { painless abortion, } 20 \text { weeks } \\
\text { painless abortion }\end{array}$ & $\begin{array}{l}\text { Not } \\
\text { stated }\end{array}$ & 32 \\
\hline 7 & 4 & 2 & $\begin{array}{l}2 \text { Full-term uneventful } \\
\text { pregnancies, } 18 \text { weeks } \\
\text { abortion, } 22 \text { weeks } \\
\text { abortion }\end{array}$ & $\begin{array}{c}\text { Not } \\
\text { stated }\end{array}$ & 34 \\
\hline 8 & 11 & 9 & $\begin{array}{l}\text { Suction termination of } \\
\text { pregnancy, } 28 \text { weeks } \\
\text { delivery, } 36 \text { weeks delivery, } \\
8 \text { miscarriages, the last at } \\
22 \text { weeks, several Shirodker } \\
\text { sutures }\end{array}$ & $\underset{\text { stated }}{\text { Not }}$ & 29 \\
\hline
\end{tabular}

D and $\mathrm{C}=$ Dilatation and curettage. 


\section{Results}

Group 1-In two patients (cases 1 and 2) the history was of classical cervical incompetence (table I). In some others the history was much less typical. Five of the eight patients (including the two patients with classical histories) had cervical measurements more than 2 standard deviations above the normal mean. Of the three others two had had several previous cervical sutures which might have reduced the cervical diameter.

Group 2-In only one case was information about the previous cervical dilatation available. Three of the eight primigravidae had measurements more than 2 standard deviations above the mean. The mean cervical measurement for the eight primigravidae was $31.6 \pm$ 2.0 French, which was significantly greater than for the normal primigravid pregnant group $(P<0.001)$. The parous women showed much less abnormality but one had a measurement over 2 standard deviations above the mean, and the mean measurement of $30 \cdot 3 \pm 4 \cdot 1$ French was probably significantly greater than that in the normal parous pregnant group $(\mathrm{P}<0.05)$.

Group 3-There was a highly significant correlation between the maximum dilatation of the cervix at operation and the cervical diameter six weeks later $(r=0.49 ; \mathrm{P}<0.001)$ (table II). The mean cervical diameter of the 38 women whose cervix was dilated to $10 \mathrm{~mm}$ or less was not significantly greater than the non-pregnant value, and only one patient had a measurement more than 2 standard deviations above the normal mean. In the 13 patients whose cervix was dilated above $10 \mathrm{~mm}$ the mean was greater than the non-pregnant mean value $(\mathrm{P}<0.001)$.

Group 4-In six of the 17 cases the cervix had been dilated to $10 \mathrm{~mm}$ (table II). The mean for these cases was not significantly different from the standard non-pregnant value. In the remaining 11 patients previous cervical dilatation had been to $12 \mathrm{~mm}$ ( 3 cases) or to $14 \mathrm{~mm}$ or more ( 3 cases), or was not known (5 cases). The mean cervical measurement for this group $(26.7 \pm 4 \cdot 3)$ was higher than the standard non-pregnant value $(P<0.05)$ and one patient had a measurement more than 2 standard deviations above the mean.

TABLE II-Cervical measurements in patients six weeks after suction termination of pregnancy (group 3) and 17 patients more than a year after suction termination (group 4)

\begin{tabular}{|c|c|c|c|}
\hline $\begin{array}{l}\text { Dilatation of } \\
\text { cervix at } \\
\text { termination of } \\
\text { pregnancy } \\
(\mathrm{mm})\end{array}$ & $\begin{array}{c}\text { No of } \\
\text { patients }\end{array}$ & $\begin{array}{c}\text { Mean }( \pm S D) \\
\text { cervical } \\
\text { measurement } \\
\text { (French gauge) }\end{array}$ & $\begin{array}{l}\text { No of patients } \\
\text { with values over } \\
2 S D \text { above } \\
\text { non-pregnant } \\
\text { mean }\end{array}$ \\
\hline \multicolumn{4}{|c|}{ Group 3} \\
\hline $\begin{array}{r}8 \\
10 \\
12 \\
-14\end{array}$ & $\begin{array}{r}18 \\
20 \\
7 \\
6\end{array}$ & $\begin{array}{l}24 \cdot 8+2 \cdot 5 \\
25 \cdot 5 \div 2 \cdot 8 \\
25 \cdot 9 \pm 3 \cdot 6 \\
31 \cdot 7 \pm 6 \cdot 1\end{array}$ & $\begin{array}{l}0 \\
1 \\
1 \\
4\end{array}$ \\
\hline \multicolumn{4}{|c|}{ Group 4} \\
\hline $\begin{array}{c}10 \\
12 \\
14 \\
\text { Not known }\end{array}$ & $\begin{array}{l}6 \\
3 \\
3 \\
5\end{array}$ & $\begin{array}{l}25 \cdot 2 \div 2 \cdot 1 \\
26 \cdot 0 \div 0 \\
27 \cdot 7 \div 2 \cdot 3 \\
26 \cdot 6=6 \cdot 1\end{array}$ & \\
\hline
\end{tabular}

\section{Discussion}

The results in group 1 confirm what is well recognised, that patients with a history of cervical incompetence tend to have abnormally large cervical diameters. Also some patients have high cervical measurements after suction termination of pregnancy (groups 2, 3, and 4). Obviously these women will not necessarily have cervical incompetence, which is uncommon. What is likely, however, is that the higher the cervical diameter the greater will be the risk of this. In the 45 patients in whom previous cervical dilatation had been $10 \mathrm{~mm}$ or less the subsequent cervical diameters were normal. Many of the 29 patients who had undergone dilatation to more than $12 \mathrm{~mm}$ or to unknown amounts had high cervical measurements.

There are two criticisms of the obvious explanation that the higher cervical measurements resulted from higher initial cervical dilatation. The first concerns the patients in group 3 . The cervix may not have returned completely to its interval state by six weeks after termination of pregnancy and hence possibly the cervical diameter of these patients might have decreased further if measured later. The second criticism is that, although no information about previous cervical dilatation was available for the patients in group 2 , by including them with others whose cervices are known to have been dilated to $12 \mathrm{~mm}$ and more we imply that they also underwent higher cervical dilatation. This inclusion, however, is probably justified, since most of the abortions were done before 1970, when suction termination was done later in pregnancy, with larger suction cannulae, and the dangers of over-zealous cervical dilatation were not generally appreciated. Thus Stallworthy et al, ${ }^{2}$ reviewing the complications of abortion in Oxford, reported that in cases of vacuum aspiration "Hegar dilators larger than No 12 were required in the majority of cases and larger than No 14 in a fair number." $\mathrm{He}$ also reported that demonstrable cervical laceration occurred in $4.9^{\circ} \%$ of the 768 patients aborted by this method.

Hulka et $a l^{3}$ reported that maximum resistance to dilatation of the internal os in first trimester pregnancies occurs consistently at $9 \mathrm{~mm}$. They thought that the internal os dilates with ease to $8 \mathrm{~mm}$ but that the more difficult dilatation to $11 \mathrm{~mm}$ or $12 \mathrm{~mm}$ "may represent tearing of the internal os rather than true dilatation." With present abortion techniques, however, terminations are performed at an earlier gestation and cervical dilatation is accomplished more gently with tapered dilators and local instead of general anaesthesia. Thus pregnancies up to 10 weeks can be evacuated easily with plastic cannulae of up to $10 \mathrm{~mm}$, although pregnancies of 12 weeks are evacuated more rapidly and with less blood loss with suction cannulae of $12 \mathrm{~mm}$.

In conclusion, while the limitations of this small study must be kept in mind, our data suggest that dilatation of the cervix to $14 \mathrm{~mm}$ or above (and possibly even to $12 \mathrm{~mm}$ ) at suction termination of pregnancy may result in abnormally high cervical measurements in some patients, and hence may increase the small possibility of second trimester abortion or premature labour from cervical incompetence. No such association is found when the cervix is dilated to $10 \mathrm{~mm}$ or less.

\section{References}

1 Johnstone, F D, et al, Fournal of Obstetrics and Gynaecology of the British Commonwealth, 1974, 81, 558 .

2 Stallworthy, J A, Moolgaoker, A S, and Walsh, J J, Lancet, 1971, 2, 1245.

${ }^{3}$ Hulka, J F, et al, American fournal of Obstetrics and Gynecology, 1974, $120,166$. 